NOTICE: this is the author's version of a work that was accepted for publication in the European Journal of Medicinal Chemistry. Changes resulting from the publishing process, such as peer review, editing, corrections, structural formatting, and other quality control mechanisms may not be reflected in this document. Changes may have been made to this work since it was submitted for publication. A definitive version was subsequently published in the European Journal of Medicinal Chemistry, Vol. 63 (2013). DOI:

10.1016/j.ejmech.2013.02.003 


\section{Synthesis, local anaesthetic and antiarrhythmic activities of $N$-alkyl derivatives of proline anilides}

Dmitrii V. Kalinin, ${ }^{a}$ Vladimir I. Pantsurkin, ${ }^{a}$ Boris Ya. Syropyatov, ${ }^{\text {a }}$ Svetlana A. Kalinina, ${ }^{a}$ Irina P. Rudakova, ${ }^{a}$ Mikhail I. Vakhrin ${ }^{a}$ and Anton V. Dolzhenko, ${ }^{\text {b,** }}$

${ }^{a}$ Perm State Pharmaceutical Academy, 2 Polevaya Street, Perm 614990, Russian Federation

${ }^{b}$ Jeffrey Cheah School of Medicine and Health Sciences, Monash University Sunway Campus, Jalan Lagoon Selatan, Bandar Sunway, Selangor 46150, Malaysia

${ }^{c}$ School of Pharmacy, Curtin Health Innovation Research Institute, Curtin University, GPO Box U1987 Perth, Western Australia 6845, Australia

* Corresponding author. Tel.: +61-8-9266-3747; fax: +61-8-9266-2769.

E-mail addresses: DolzhenkoAV@gmail.com; Anton.Dolzhenko@monash.edu;

A.Dolzhenko@curtin.edu.au (A. V. Dolzhenko) 


\begin{abstract}
We describe here the design, synthesis and evaluation of in vivo local anaesthetic and antiarrhythmic activities of a series of $\mathrm{N}$-alkylproline anilides. Most of the compounds demonstrated surface anaesthetic activity higher than that of lidocaine, ropivacaine and bupivacaine. We established that the local anaesthetic activity was sensitive to structural variations in the substitution pattern at the aromatic ring and the type of alkyl group at the proline nitrogen atom. Some of the prepared $\mathrm{N}$-alkylproline anilides possessed significant antiarrhythmic activity with higher therapeutic indexes than the reference drugs.
\end{abstract}

\title{
Keywords:
}

Local anesthetic

Surface anesthesia

Infiltration anesthesia

Antiarrhythmic

Proline derivative

Anilide 


\section{Introduction}

Local anaesthetics are drugs clinically used to produce reversible loss of sensation in a confined area of the body. Nowadays local anaesthetics play an important role in clinical management of acute, chronic and cancer pain [1-3]. Moreover local anaesthetics represent one of the most frequently used in daily medical practice groups of drugs [4]. At the same time, application of available anaesthetics was reported [5,6] to induce some severe adverse effects including life threatening conditions, signifying therefore importance of development of new safer local anaesthetic agents.

The first clinically available amide based local anaesthetic, lidocaine (Fig. 1), was synthesized by Swedish chemist Nils Lofgren in 1943 [7]. This drug was characterized by fast onset of action, strong and relatively long lasting effect, exceeded by these parameters ester based anaesthetics of that time. Lidocaine opened a new avenue for development of local anaesthetics and its structural features, such as tertiary amino group and arylamide moiety connected with one carbon atom, became a classical pattern for most of the modern local anaesthetics (Fig. 1). In the process of development of new more potent local anesthetics, $N, N$-dialkyl derivatives of glycine evolved to $N$-alkyl substituted homoprolines and prolines. Thus Ekenstam introduced homoprolinebased mepivacaine, bupivacaine and ropivacaine (Fig. 1) in clinical practice as very potent local anaesthetics [8-10]. At the same time effective anaesthetics, derivatives of proline, namely cyclomecaine and pyromecaine were developed [11]. However, therapeutic application of these drugs is limited due to their substantial general toxicity [12] and associated side effects[13,14]. Furthermore, a discovery of antiarrhythmic properties of lidocaine in the event of ventricular fibrillation during cardiac catheterisation [15] initiated a number of studies devoted to search of new local anaesthetics and antiarrhythmics among arylamides of $\alpha$-amino acids $[16,17]$. It has been established that both the anaesthetic and antiarrhythmic effects realise via the same mechanism involving mainly blocking voltage-gated sodium [18], calcium [19] and to some extent potassium [20] channels thus causing membrane stabilisation and therefore preventing initiation of the action potentials. Since that time, further development of anaesthetic and antiarrhythmic drugs has been often parallel.

Although the main trend in modern drug design and development inclines towards search for agents highly selective against one particular target, it appears that all clinically available anaesthetics are scarcely selective to any specific type and subtype of the ion channels. They all have been discovered on the basis of in vitro and in vivo tests assessing changes in the neurone functions. This can be attributed to incomplete knowledge of actual role of each type and subtypes 
of the ion channels in the activity. Therefore it seems practical to conduct search for new anaesthetic and antiarrhythmic agents using assays based on the desirable therapeutic outcome.

In this study we focus on the compounds with the $N$-alkyl proline core, which seems to be preferable over $N$-alkyl homoproline due to lower toxicity of the derivatives based on this scaffold [9]. Herein we report synthesis and biological activity of $\mathrm{N}$-alkyl derivatives of proline anilides, which can be considered as structural analogues of cyclomecaine, one of the most potent modern local anaesthetics $[11,21]$. Effects of two types of structural variations on the anaesthetic and antiarrhythmic activity were explored: (1) substituents on the phenyl ring of the anilide fragments and (2) type of alkyl group at the nitrogen atom of the proline fragment. The activity and toxicity of the compounds were compared with structurally related cyclomecaine and widely used anaesthetics lidocaine, bupivacaine and ropivacaine.

\section{Chemistry}

The synthesis of $\mathrm{N}$-alkyl derivatives of proline anilides (4) for pharmacological investigations was performed as outlined in Scheme 1. The design of the synthetic pathway allowed exploration of substitution at the two critical for biological activity positions of the final compounds 4. The bromination of 5-chloropentanoic acid (1) in $\alpha$-position using molecular bromine in the presence of phosphorus trichloride afforded 2-bromo-5-chloropentanoic acid, which was converted into corresponding acid chloride 2. Then arylamides of 2-bromo-5-chloropentanoic acid (3) were prepared by treatment of $\mathbf{2}$ with various anilines in mild conditions. The treatment of $\mathbf{3}$ with primary alkylamines under heating in toluene resulted in the intramolecular cyclization with formation of arylamides of $\mathrm{N}$-alkylprolines, which were further converted into the corresponding hydrochloric salts 4. ortho-Toluidide of $N$-methylproline (4a) has been previously reported and its physicochemical and spectral characteristics are in agreement with the literature values [22].

In DMSO solution, most of the anilides of $N$-alkylproline hydrochlorides (4) appeared as a mixture of two diastereomers due to the second stereogenic center introduced by protonation of the proline nitrogen. The diastereomer ratio depends on the type of substituents and conditions of the NMR experiments. Thus, only one cis-form was observed for $\mathbf{4 a}$ and $\mathbf{4 m}$. Despite of evident stabilization of the trans-form via intramolecular hydrogen bonding, this form was always minor and its content in the mixture never exceeded $20 \%$. 


\section{Results and discussion}

All synthesised compounds (4a-4p) were evaluated in vivo for their local anaesthetic and antiarrhythmic activities. Initial screening of the compounds for local anaesthetic activity was performed using a commonly used surface anaesthesia model on rabbit cornea [23]. Further elaboration in the rat infiltration anaesthesia model [24] was carried out for the most promising compounds.

\subsection{Surface local anaesthetic activity}

Surface anaesthetic activity of the compounds was evaluated in white New Zealand rabbits using the corneal reflex test [23]. This test was used as the initial screening model due to its high sensitivity and relative simplicity. Most of the prepared compounds were found to possess surface anaesthetic activity in this test at $1 \%$ concentration (Table 1 ).

The results of structure-activity relationship analysis revealed some important features responsible for the anaesthetic effect of the compounds. Classical substitution pattern in the aromatic ring of local anaesthetics of the arylamide class (Fig. 1) typically include at least one methyl group in the ortho-position (e.g. prilocaine), more often two (e.g. lidocaine, bupivacaine and ropivacaine) and sometimes the third one in para-position (e.g. trimecaine, cyclomecaine and pyromecaine). We also found that in our series of compounds, methyl substituent was optimal for the activity. Even slight increase in the length of the alkyl chain from methyl (compound $\mathbf{4 c}$ ) to ethyl (4g) group dramatically reduced surface local anaesthetic activity. We believe that this fact was linked with a clearly observable local irritative effect of $\mathbf{4 g}$. Similarly to the previously reported data $[9,22]$, we found that increase in the number of methyl groups translated into increase of potency and duration of local anaesthetic effect. Interestingly, 2,4- and 2,6-xylidides (4d and $\mathbf{4 e}$ ) demonstrated almost no difference in the activity. Changing the ortho-methyl to trifluoromethyl group or a halogen significantly decreased depth and duration of the surface anaesthesia. Introduction of a second halogen in para-position resulted in complete loss of anaesthetic effect.

Type of the $N$-alkyl substituent at the pyrrolidine ring was found to be critical for the surface local anaesthetic activity. The $N$-methyl and ethyl substituted $\mathbf{4 a}$ and $\mathbf{4 b}$ possessed no anaesthetic activity in this assay. It appeared that the alkyl substituent should contain more than two carbon atoms. Extension of the chain from $n$-butyl (4c) to $n$-pentyl (4k) and further to $n$-hexyl (4I) in $N$ alkyl proline ortho-toluidides led to some increase of the Regnier index and significantly 
lengthened the anaesthetic activity. Making the alkyl chain even longer seemed to be unnecessary due to local irritative effect and poor aqueous solubility, previously reported for the similar structures with longer $N$-alkyl chain in the pyrrolidine ring [22]. The cyclohexyl substituted derivatives $4 \mathbf{n}$ and $\mathbf{4 o}$ demonstrated practically the same level and duration of anaesthesia as their corresponding $n$-butyl analogues $\mathbf{4 c}$, e. Interestingly, despite recent reports [25-27] on high in vitro sodium channel blocking potential of 2,6-xylidine analogue of $\mathbf{4 m}$ - NeP1 (Fig. 1), introduction of a $N$-benzyl moiety into the pyrrolidine ring of ortho-toluidine derivative appeared to abolish anaesthetic activity. All the above observations were found to be very close to those earlier reported [22] for the analogous mesidides and seemed to be general for this class of local anaesthetics.

\subsection{Infiltration local anaesthetic activity}

The most active in the surface local anaesthesia test compounds $(\mathbf{4 d}, \mathbf{4 l}$ and $\mathbf{4 o}$ ) were subjected to the infiltration anaesthesia assay in rats [24]. The anaesthetic activity was assessed by the onset, depth and duration of the muscle contraction blockade. The contractions were stimulated by electrical current $(0.3 \mathrm{~ms}, 50 \mathrm{~Hz}, 0.36-14.0 \mathrm{~V})$. The depth of anaesthesia was expressed as a percentage increase of the initial value of stimulation threshold. An increase of the stimulation threshold value more than 2 times from initial values was considered as a complete (100\%) anaesthesia. To gain further understanding of a role of the second methyl group in the arylamino moiety, ortho-toluidide derivative $\mathbf{4 c}$ was also tested in the assay and its effect was compared with that of 2,6-xylidide substituted analogue $\mathbf{4 d}$.

All compounds and reference drugs demonstrated fast onset of action blocking muscle contractions within 1-2 min after administration. The duration of anaesthesia caused by the tested compounds 4c, 4d, $4 \mathbf{l}$ and $\mathbf{4 o}$ ranged between $35.0 \pm 4.1$ and $126.3 \pm 24.3 \mathrm{~min}$. Similarly to the reference drugs bupivacaine and ropivacaine, compound 4c (Fig. 2A) completely blocked the muscle contraction at the first minute. However duration of the complete anaesthesia for $\mathbf{4 c}$ was shorter $(12.5 \pm 2.9 \mathrm{~min})$ compare to bupivacaine and ropivacaine, which completely prevent the stimulated muscle contraction for $102.5 \pm 37.9$ and $58.8 \pm 17.5 \mathrm{~min}$, respectively. The depth of anaesthesia for compound $\mathbf{4 c}$ decreased sharply and the threshold values return to the normal in 35.0 $\pm 4.1 \mathrm{~min}$ after application.

Compound 4d, 2,6-xylidine analogue of $\mathbf{4 c}$, with the higher surface anaesthetic activity demonstrated only $90 \%$ increase of the threshold values in the infiltration anaesthesia assay (Fig. 
2B). However duration of the anaesthetic action for $\mathbf{4 d}$ was longer with the maximal block lasted for $20.0 \pm 13.5 \mathrm{~min}$ followed by slow recovery. No significant difference with the initial threshold values was observed in $71.3 \pm 19.3$ min after administration of $\mathbf{4 d}$.

Compounds $4 \mathbf{l}$ and 40 were practically equipotent in terms of depth and duration of the surface local anaesthesia, but these compounds demonstrated distinct profiles in the infiltration anaesthesia assay (Figs. 2C and 2D). Both compounds possessed long-acting local anaesthetic activity exceeding the effect duration of ropivacaine $(80.0 \pm 15.8 \mathrm{~min})$. Thus, $\mathbf{4 l}$ was effective for 115.0 $\pm 12.2 \mathrm{~min}$, while 4o induced even longer $(126.3 \pm 24.3 \mathrm{~min})$ infiltration anaesthesia. Bupivacaine was found to be active for $155.0 \pm 11.5 \mathrm{~min}$ with $102.5 \pm 37.9 \mathrm{~min}$ of the complete anaesthesia.

In general, 4d, $\mathbf{4 l}$ and 40 were more active than lidocaine, ropivacaine and bupivacaine in inducing surface anaesthesia, though duration of their effects was shorter than that of bupivacaine. At the same time, these compounds $(\mathbf{4 d}, \mathbf{4 l}$ and $\mathbf{4 o}$ ) were less potent in the infiltration anaesthesia assay than bupivacaine and seemed to be less suitable for this type of therapeutic applications. Significantly lower toxicity of $\mathbf{4 0}$ compare to the reference drugs (vide infra) was one of the main advantages making this compound a suitable candidate for further investigations.

\subsection{Antiarrhythmic activity}

Antiarrhythmic activity of the synthesized compounds was estimated by their ability to prevent mortality in the event of calcium chloride induced arrhythmia in mice [28]. To exclude contribution of the intrinsic toxicity of the compounds to the mortality, acute toxicity $\left(\mathrm{LD}_{50}\right)$ [29] of the compounds in mice was estimated prior to their testing in the antiarrhythmic assay. Effective dose $\left(\mathrm{ED}_{50}\right)$ was determined only when it was less than $1 / 2$ of $\mathrm{LD}_{50}$.

In general, the compounds active in the anaesthetic tests also were found to be effective in the antiarrhythmic assay. However, unlike the local anaesthetic activity, antiarrhythmic properties of the compounds tolerated various types of ortho-subtituents at the phenyl ring if other positions remained intact. Moreover, ortho-methyl substituted compounds were more toxic than their corresponding analogues. Introduction of the second methyl group in position 4 (para) decreased toxicity of the compounds (4e and 4o), while the same group in position 6 (ortho) significantly increased toxicity (4d). It seems that for cyclomecaine with the 2,4,6-trimethyl substitution, methyl 
groups in positions 4 and 6 cancelled effects of each other in terms of toxicity, but appeared to be very beneficial for the antiarrhythmic effect.

Similarly to the local anaesthetic activity, four or more carbons in the chain of $N$-alkyl substituent at the pyrrolidine ring were required for the compounds to possess antiarrhythmic properties. $N$-Methyl and ethyl substituted $\mathbf{4 a}$ and $\mathbf{4 b}$ were inactive at the tested doses. However, in contrast to the local anaesthetic activity, increasing the alkyl group size did not correlate with improvement of antiarrhythmic activity. $N$-Benzyl substituted $\mathbf{4 m}$, which was inactive in the surface local anaesthesia assay, appeared to be effective in the prevention of calcium chloride induced arrhythmia in mice.

In general, six compounds (4f, 4h, 4k, 4l, 4o and 4p) exhibited better than the reference drugs antiarrhythmic/toxicity profile. The combination of $N$-cyclohexyl substitution in pyrrolidine ring and 2,4-xylidide moiety (compound 4o) were found to be optimal, balancing high potency and relatively low toxicity. Antiarrhythmic index of this compound (7.3) significantly exceeded the same parameter of the reference drugs. Another even less toxic candidate for further development as an antiarrhythmic agent could be $\mathbf{4 p}$ with the antiarrhythmic index of 6.9 .

\section{Conclusion}

$N$-Alkyl derivatives of proline anilides (4) were synthesized and proved to be a prospective group for the search of new local anaesthetic and antiarrhythmic agents. Among the tested compounds, $N$-cyclohexyl substituted proline 2,4-xylidide (4o) was the most promising compound in terms of surface anaesthetic and antiarrhythmic actions possessing at the same time significantly lower toxicity than the reference drugs. Toluidide $4 \mathbf{l}$ demonstrated similar potency in local anaesthetic and antiarrhythmic assays together with lower than the reference drug toxicity. 2,6Xylidide 4d induced high level of surface anaesthesia, but was one of the most toxic in the series. ortho-Chloroanilide $4 \mathbf{p}$ exhibited relatively low anaesthetic activity, but could be interesting for further development as an antiarrhythmic agent with low toxicity. 


\section{Experimental}

\subsection{Chemistry}

Melting points (uncorrected) were determined on a Gallenkamp melting point apparatus in open capillaries. The ${ }^{1} \mathrm{H}$ NMR spectra were recorded on a Mercury-300BB spectrometer (300 MHz) in $\mathrm{CDCl}_{3}$ and DMSO- $d_{6}$ using TMS as an internal standard.

\subsubsection{2-Bromo-5-chloropentanoic acid (2)}

5-Chloropentanoic acid $(1,52.2 \mathrm{~g}, 0.382 \mathrm{~mol})$ and dry bromine $(76.8 \mathrm{~g}, 0.480 \mathrm{~mol})$ in the presence of phosphorus trichloride $(4 \mathrm{ml}, 45.8 \mathrm{mmol})$ were heated on water bath at $80^{\circ} \mathrm{C}$ for $20 \mathrm{~h}$, then the heating was continued at $100^{\circ} \mathrm{C}$ for $2 \mathrm{~h}$. After cooling to ambient temperature, the reaction mixture was treated with $250 \mathrm{ml}$ of water. The organic layer was extracted with benzene (3 times). After drying over anhydrous $\mathrm{MgSO}_{4}$, the solvent was evaporated under reduced pressure to give $75.1 \mathrm{~g}$ of 2-bromo-5-chloropentanoic acid (2) as oil. ${ }^{1} \mathrm{H}$ NMR $\left(\mathrm{CDCl}_{3}\right), \delta(\mathrm{ppm}): 1.72-2.40(\mathrm{~m}, 4 \mathrm{H})$, $3.53(\mathrm{t}, 2 \mathrm{H}, J=5.6 \mathrm{~Hz}), 4.23(\mathrm{dd}, 1 \mathrm{H}, J=7.4,6.5 \mathrm{~Hz}), 10.46$ (br. s, $1 \mathrm{H})$. Anal. Calc. for $\mathrm{C}_{5} \mathrm{H}_{8} \mathrm{BrClO}_{2}$ : C, 27.87; H, 3.74. Found: C, 27.74; H, 3.51.

\subsubsection{2-Bromo-5-chloropentanoic acid chloride (3)}

2-Bromo-5-chloropentanoic acid (2) was mixed with thionyl chloride (0.870 mol, $103.6 \mathrm{~g})$ and heated under reflux in water bath for $1.5 \mathrm{~h}$. The excess of thionyl chloride was removed under reduced pressure affording $72.9 \mathrm{~g}$ of 2-bromo-5-chloropentanoic acid chloride $(3) .{ }^{1} \mathrm{H}$ NMR $\left(\mathrm{CDCl}_{3}\right), \delta(\mathrm{ppm}): 1.74-2.42(\mathrm{~m}, 4 \mathrm{H}), 3.55(\mathrm{t}, 2 \mathrm{H}, J=6.1 \mathrm{~Hz}), 4.51(\mathrm{dd}, 1 \mathrm{H}, J=7.4,5.6 \mathrm{~Hz})$. Anal. Calc. for $\mathrm{C}_{5} \mathrm{H}_{7} \mathrm{BrCl}_{2} \mathrm{O}$ : C, 25.67; H, 3.02. Found: C, 25.46; H, 2.94.

\subsubsection{Hydrochlorides of o-toluidide of $N$-methylproline (4a) and o-toluidide of $N$-ethylproline (4b)}

Solution of 2-bromo-5-chloropentanoic acid chloride (2, $23.4 \mathrm{~g}, 100 \mathrm{mmol})$ in chloroform (40 ml) was added dropwise at $0-5{ }^{\circ} \mathrm{C}$ during $45 \mathrm{~min}$ to the mixture of $o$-toluidine $(10.72 \mathrm{~g}, 100$ $\mathrm{mmol})$ and triethylamine $(10.1 \mathrm{~g}, 100 \mathrm{mmol})$ in chloroform $(50 \mathrm{ml})$ and the reaction mixture was heated under reflux for $1 \mathrm{~h}$. After cooling, the mixture was treated with 3\% hydrochloric acid (100 $\mathrm{ml}$ ) and the organic layer was collected, washed with water to neutral $\mathrm{pH}$ and evaporated. The residue was recrystallized from hexane to give $o$-toluidide of 2-bromo-5-chloropentanoic acid (3), which was dissolved in toluene $(30 \mathrm{mmol}$ in $100 \mathrm{ml})$, mixed with potassium iodide $(0.2 \mathrm{~g}, 1.2$ mmol) and treated with dry gaseous methylamine or ethylamine via bubbling for $6 \mathrm{~h}$. The precipitate was filtered off and the filtrate was treated with saturated $\mathrm{K}_{2} \mathrm{CO}_{3}$ aqueous solution (100 
$\mathrm{ml}$ ). The organic layer was collected, dried over anhydrous $\mathrm{MgSO}_{4}$ and evaporated under reduced pressure. The residue was dissolved in dry diethyl ether and treated with gaseous $\mathrm{HCl}$. The precipitated product was filtered, washed with acetone and recrystallized from acetonitrile (for $\mathbf{4 a}$ ) or acetone/diethyl ether (for $\mathbf{4 b}$ ) providing corresponding $o$-toluidides of $N$-alkylproline hydrochlorides (4a and $\mathbf{4 b}$ ).

\subsubsection{1. o-Toluidide of $N$-methylproline (4a)}

Yield 74\%; mp 219-221 ${ }^{\circ} \mathrm{C}(\mathrm{MeCN}) ;{ }^{1} \mathrm{H}$ NMR (DMSO- $\left.d_{6}\right), \delta(\mathrm{ppm}): 1.82-2.12(\mathrm{~m}, 2 \mathrm{H})$, $2.22(\mathrm{~s}, 3 \mathrm{H}), 2.55-2.70(\mathrm{~m}, 2 \mathrm{H}), 2.85(\mathrm{~s}, 3 \mathrm{H}), 3.42-3.68(\mathrm{~m}, 2 \mathrm{H}), 4.43(\mathrm{dt}, 1 \mathrm{H}, J=7.8,8.4 \mathrm{~Hz})$, 6.98-7.38 (m, 4H, Ar), 9.85 (br. s, $1 \mathrm{H}$ ), 10.59 (s, 1H). Anal. Calc. for $\mathrm{C}_{13} \mathrm{H}_{19} \mathrm{ClN}_{2} \mathrm{O}: \mathrm{C}, 61.29 ; \mathrm{H}$, 7.52; N, 11.00. Found: C, 61.13; H, 7.41; N, 10.91 .

\subsubsection{2. o-Toluidide of $N$-ethylproline $(4 \boldsymbol{b})$}

Yield 52\%; mp $188{ }^{\circ} \mathrm{C}$ (acetone/Et $\left.2 \mathrm{O}\right) ;{ }^{1} \mathrm{H}$ NMR (DMSO- $\left.d_{6}\right), \delta(\mathrm{ppm}): 1.24$ (t, 3H, $J=6.9$ $\mathrm{Hz}), 1.89-2.18$ (m, 2H), $2.23(\mathrm{~s}, 3 \mathrm{H}), 2.60-2.71(\mathrm{~m}, 2 \mathrm{H}), 3.19-3.32(\mathrm{~m}, 2 \mathrm{H}), 3.60-3.72(\mathrm{~m}, 2 \mathrm{H}), 4.48$ (dt, $1 \mathrm{H}, J=8.1,7.5 \mathrm{~Hz}), 4.70^{*}(\mathrm{~m}, 1 \mathrm{H}), 7.12-7.39$ (m, 4H, Ar), 9.60 (br. s,1H), 10.28* (s, 1H), $10.59(\mathrm{~s}, 1 \mathrm{H}), 11.99 *$ (br. s, 1H); * signals of the minor trans-diastereomer. Anal. Calc. for $\mathrm{C}_{14} \mathrm{H}_{21} \mathrm{ClN}_{2} \mathrm{O}$ : C, 62.56; H, 7.88; N, 10.42. Found: C, 62.39; H, 7.72; N, 10.37 .

\subsubsection{Hydrochlorides of anilides of $N$-alkylproline $(4 c-4 p)$}

Solution of 2-bromo-5-chloropentanoic acid chloride $(2,23.4 \mathrm{~g}, 100 \mathrm{mmol})$ in chloroform (40 ml) was added dropwise at $0-5{ }^{\circ} \mathrm{C}$ during $45 \mathrm{~min}$ to the mixture of substituted aniline (100 mmol) and triethylamine $(10.1 \mathrm{~g}, 100 \mathrm{mmol})$ in chloroform $(50 \mathrm{ml})$ and the reaction mixture was heated under reflux for $1 \mathrm{~h}$. After cooling, the mixture was treated with 3\% hydrochloric acid (100 $\mathrm{ml}$ ) and the organic layer was collected, washed with water to neutral $\mathrm{pH}$ and evaporated. The residue was recrystallized from hexane to give anilides of 2-bromo-5-chloropentanoic acid (3), which were dissolved in toluene $(30 \mathrm{mmol}$ in $100 \mathrm{ml})$, mixed with triethylamine $(6.1 \mathrm{~g}, 60 \mathrm{mmol})$ and primary alkylamine $(45 \mathrm{mmol})$. Then potassium iodide $(0.2 \mathrm{~g}, 1.2 \mathrm{mmol})$ was added and the reaction mixture was heated under reflux for $25 \mathrm{~h}$. After cooling, the precipitate was filtered off and the filtrate was treated with saturated $\mathrm{K}_{2} \mathrm{CO}_{3}$ aqueous solution $(100 \mathrm{ml})$. The organic layer was collected, dried over anhydrous $\mathrm{MgSO}_{4}$ and evaporated under reduced pressure. The residue was dissolved in dry diethyl ether and treated with gaseous $\mathrm{HCl}$. The precipitated product was filtered, washed with acetone and recrystallized from appropriate solvent providing anilides of $N$ alkylproline hydrochlorides (4). 


\subsubsection{1. o-Toluidide of $\mathrm{N}$-butylproline (4c)}

Yield 55\%; mp 202-204 ${ }^{\circ} \mathrm{C}(1,4-$ dioxane/toluene, $1: 1) ;{ }^{1} \mathrm{H}$ NMR (DMSO- $\left.d_{6}\right), \delta$ (ppm) 0.85 (t, 3H, $J=6.5 \mathrm{~Hz}), 1.22-1.38(\mathrm{~m}, 2 \mathrm{H}), 1.48-1.80(\mathrm{~m}, 2 \mathrm{H}), 1.92-2.10(\mathrm{~m}, 2 \mathrm{H}), 2.16(\mathrm{~s}, 3 \mathrm{H}), 2.56-$ $2.64(\mathrm{~m}, 2 \mathrm{H}), 3.12-3.34(\mathrm{~m}, 2 \mathrm{H}), 3.50-3.75(\mathrm{~m}, 2 \mathrm{H}), 4.36-4.80(\mathrm{~m}, 1 \mathrm{H}), 6.95-7.34(\mathrm{~m}, 4 \mathrm{H}, \mathrm{Ar}), 9.50$ (br. s, 1H), 10.32* (s, 1H), $10.70(\mathrm{~s}, 1 \mathrm{H}), 11.98^{*}$ (br. s, 1H); * - signals of the minor transdiastereomer. Anal. Calc. for $\mathrm{C}_{16} \mathrm{H}_{25} \mathrm{ClN}_{2} \mathrm{O}$ : C, 64.74; H, 8.49; N, 9.44. Found: C, 64.60; H, 8.36; N, 9.38 .

\subsubsection{1,6-Xylidide of $N$-butylproline $(\mathbf{4 d})$}

Yield 64\%; mp 244-246 ${ }^{\circ} \mathrm{C}(i-\mathrm{PrOH}) ;{ }^{1} \mathrm{H}$ NMR (DMSO- $\left.d_{6}\right), \delta$ (ppm) 0.90 (t, 3H, $J=6.9$ $\mathrm{Hz}), 1.22-1.38(\mathrm{~m}, 2 \mathrm{H}), 1.52-1.78(\mathrm{~m}, 2 \mathrm{H}), 1.91-2.10(\mathrm{~m}, 2 \mathrm{H}), 2.15(\mathrm{~s}, 6 \mathrm{H}), 2.42-2.58(\mathrm{~m}, 2 \mathrm{H})$, 3.12-3.28 (m, 2H), 3.51-3.68 (m, 2H), 4.38-4.78 (m, 1H), 6.90-7.15 (m, 3H, Ar), 9.45 (br. s, 1H), $10.35^{*}$ (br. s, 1H), $10.70(\mathrm{~s}, 1 \mathrm{H}), 11.95^{*}$ (br. s, 1H); * signals of the minor trans-diastereomer. Anal. Calc. for $\mathrm{C}_{17} \mathrm{H}_{27} \mathrm{ClN}_{2} \mathrm{O}$ : C, 65.68; H, 8.75; N, 9.01. Found: C, 65.66; H, 8.68; N, 8.94.

\subsubsection{1,4-Xylidide of $N$-butylproline (4e)}

Yield 58\%; mp 182-184 ${ }^{\circ} \mathrm{C}$ (1,4-dioxane/toluene, 1:1); ${ }^{1} \mathrm{H}$ NMR (DMSO- $\left.d_{6}\right), \delta$ (ppm) 0.88 (t, 3H, $J=6.5 \mathrm{~Hz}), 1.25-1.40(\mathrm{~m}, 2 \mathrm{H}), 1.50-1.75(\mathrm{~m}, 2 \mathrm{H}), 1.85-2.10(\mathrm{~m}, 2 \mathrm{H}), 2.15(\mathrm{~s}, 3 \mathrm{H}), 2.25(\mathrm{~s}$, $3 \mathrm{H}), 2.50-2.70(\mathrm{~m}, 2 \mathrm{H}), 3.09-3.28(\mathrm{~m}, 2 \mathrm{H}), 3.48-3.71(\mathrm{~m}, 2 \mathrm{H}), 4.35-4.65(\mathrm{~m}, 1 \mathrm{H}), 6.89(\mathrm{~d}, 1 \mathrm{H}, J=$ $7.4 \mathrm{~Hz}), 6.94(\mathrm{~s}, 1 \mathrm{H}), 7.11$ (d, 1H, J = $7.4 \mathrm{~Hz}), 9.50$ (br. s, 1H), 10.05* (s, 1H), 10.65 (s, 1H), $11.97 *$ (br. s, $1 \mathrm{H}$ ); * - signals of the minor trans-diastereomer. Anal. Calc. for $\mathrm{C}_{17} \mathrm{H}_{27} \mathrm{ClN}_{2} \mathrm{O}: \mathrm{C}$, 65.68; H, 8.75; N, 9.01. Found: C, 65.58; H, 8.64; N, 8.90.

\subsubsection{4. o-Trifluoromethylanilide of $N$-butylproline $(\mathbf{4 f})$}

Yield 62\%; mp 210-212 ${ }^{\circ} \mathrm{C}$ (MeCN/toluene, 1:1); ${ }^{1} \mathrm{H}$ NMR (DMSO- $\left.d_{6}\right), \delta(\mathrm{ppm}) 0.89(\mathrm{t}$, $3 \mathrm{H}, J=6.5 \mathrm{~Hz}), 1.21-1.40(\mathrm{~m}, 2 \mathrm{H}), 1.40-1.70$ (m, 2H), 1.88-2.20 (m, 2H), 2.54-2.71 (m, 2H), 3.16$3.34(\mathrm{~m}, 2 \mathrm{H}), 3.55-3.75(\mathrm{~m}, 2 \mathrm{H}), 4.28-4.70(\mathrm{~m}, 1 \mathrm{H}), 7.30-7.80$ (m, 4H, Ar), 9.55 (br. s, 1H), 10.56* $(\mathrm{s}, 1 \mathrm{H}), 10,90(\mathrm{~s}, 1 \mathrm{H}), 12.10^{*}$ (br. s, 1H); - signals of the minor trans-diastereomer. Anal. Calc. for $\mathrm{C}_{16} \mathrm{H}_{22} \mathrm{ClF}_{3} \mathrm{~N}_{2} \mathrm{O}$ : C, 54.78; H, 6.32; N, 7.99. Found: C, 54.69; H, 6.27; N, 7.91.

\subsubsection{5. o-Ethylanilide of $\mathrm{N}$-butylproline $\mathbf{( 4 \mathrm { g } )}$}

Yield 56\%; mp 182-184 ${ }^{\circ} \mathrm{C}$ (acetone); ${ }^{1} \mathrm{H}$ NMR (DMSO- $\left.d_{6}\right), \delta(\mathrm{ppm}) 0.88(\mathrm{t}, 3 \mathrm{H}, J=6.5$ $\mathrm{Hz}), 1.10(\mathrm{t}, 3 \mathrm{H}, J=7.4 \mathrm{~Hz}), 1.25-1.30(\mathrm{~m}, 2 \mathrm{H}), 1.40-1.70(\mathrm{~m}, 2 \mathrm{H}), 1.85-2.20(\mathrm{~m}, 2 \mathrm{H}), 2.45-2.75$ 
(m, 4H), 3.10-3.29 (m, 2H), 3.50-3.70 (m, 2H), 4.35-4.75 (m, 1H), 7.05-7.30 (m, 4H, Ar), 9.50 (br. s, $1 \mathrm{H}), 10.23 *(\mathrm{~s}, 1 \mathrm{H}), 10.63(\mathrm{~s}, 1 \mathrm{H}), 12.05^{*}$ (br. s, $\left.1 \mathrm{H}\right)$; * - signals of the minor trans-diastereomer. $\mathrm{C}_{17} \mathrm{H}_{27} \mathrm{ClN}_{2} \mathrm{O}: \mathrm{C}, 65.68 ; \mathrm{H}, 8.75 ; \mathrm{N}, 9.01$. Found: $\mathrm{C}, 65.61 ; \mathrm{H}, 8.69 ; \mathrm{N}, 8.95$.

\subsubsection{6. o-Iodoanilide of $N$-butylproline (4h)}

Yield 66\%; mp 203-205 ${ }^{\circ} \mathrm{C}$ (acetone/EtOH, 9:1); ${ }^{1} \mathrm{H}$ NMR (DMSO- $d_{6}$ ), $\delta$ (ppm) 0.89 (t, 3H, $J=7.0 \mathrm{~Hz}), 1.16-1.33(\mathrm{~m}, 2 \mathrm{H}), 1.52-1.68$ (m, 2H), 1.93-2.17 (m, 2H), 2.42-2.68 (m, 2H), 3.15-3.30 (m, 2H), 3.54-3.76 (m, 2H), 4.28-4.61 (m, 1H), 6.99 (t, 1H, J= 7.4 Hz), 7.18-7.45 (m, 2H), 7.83 (d, $1 \mathrm{H}, J=7.4 \mathrm{~Hz}$ ), 9.51 (br. s, 1H), 10.43* (s, 1H), 10.71 (s, 1H), 11.98* (br. s, 1H); * signals of the minor trans-diastereomer. Anal. Calc. for $\mathrm{C}_{15} \mathrm{H}_{22} \mathrm{ClIN}_{2} \mathrm{O}$ : C, 44.08; H, 5.43; N, 6.85. Found: C, 43.97; H, 5.38; N, 6.78.

\subsubsection{2,4-Dichloroanilide of N-butylproline (4i)}

Yield 55\%; mp 197-199 ${ }^{\circ} \mathrm{C}$ (acetone/Et $\left.2 \mathrm{O}\right) ;{ }^{1} \mathrm{H}$ NMR (DMSO- $\left.d_{6}\right), \delta(\mathrm{ppm}) 0.94(\mathrm{t}, 3 \mathrm{H}, J=$ $7.3 \mathrm{~Hz}), 1.30-1.43$ (m, 2H), 1.56-1.61 (m, 2H), 1.92-2.13 (m, 2H), 2.67-2.74 (m, 2H), 3.15-3.30 (m, 2H), 3.65-3.75 (m, 2H), $4.58(\mathrm{dt}, 1 \mathrm{H}, J=7.2,9.0 \mathrm{~Hz}), 4.77 *(\mathrm{dd}, 1 \mathrm{H}, J=7.5,4.5 \mathrm{~Hz}), 7.37-7.67$ (m, $3 \mathrm{H}, \mathrm{Ar}), 9.73$ (br. s, 1H), 10.56* (s, 1H), 11.05 (s, 1H), 12.36* (br. s, 1H); * - signals of the minor trans-diastereomer. Anal. Calc. for $\mathrm{C}_{15} \mathrm{H}_{21} \mathrm{Cl}_{3} \mathrm{~N}_{2} \mathrm{O}: \mathrm{C}, 51.23 ; \mathrm{H}, 6.02 ; \mathrm{N}, 7.97$. Found: C, 51.20; $\mathrm{H}$, $5.97 ; \mathrm{N}, 7.91$.

\subsubsection{2,4-Dibromoanilide of $\mathrm{N}$-butylproline $(\mathbf{4 j})$}

Yield 66\%; mp 192-194 ${ }^{\circ} \mathrm{C}$ (1,4-dioxane); ${ }^{1} \mathrm{H}$ NMR (DMSO- $\left.d_{6}\right), \delta$ (ppm) 0.88 (t, 3H, $J=$ $6.8 \mathrm{~Hz}), 1.22-1.43(\mathrm{~m}, 2 \mathrm{H}), 1.52-1.68(\mathrm{~m}, 2 \mathrm{H}), 1.89-2.21(\mathrm{~m}, 2 \mathrm{H}), 2.58-2.77(\mathrm{~m}, 2 \mathrm{H}), 3.12-3.27$ (m, $2 \mathrm{H}), 3.48-3.77(\mathrm{~m}, 2 \mathrm{H}), 4.32-4.71(\mathrm{~m}, 1 \mathrm{H}), 7.38(\mathrm{~d}, 1 \mathrm{H}, J=7.4 \mathrm{~Hz}), 7.58(\mathrm{~d}, 1 \mathrm{H}, J=7.4 \mathrm{~Hz}), 7.71$ (s, 1H), 9.60 (br. s, 1H), 10.60* (s, 1H), 10.90 (s, 1H), 12.05* (br. s, 1H); * - signals of the minor trans-diastereomer. Anal. Calc. for $\mathrm{C}_{15} \mathrm{H}_{21} \mathrm{ClBr}_{2} \mathrm{~N}_{2} \mathrm{O}$ : C, 40.89; H, 4.80; N, 6.36. Found: C, 40.76; H, 4.71; N, 6.27.

\subsubsection{9. o-Toluidide of $N$-pentylproline ( $4 k)$}

Yield 56\%; mp 201-203 ${ }^{\circ} \mathrm{C}$ (1,4-dioxane); ${ }^{1} \mathrm{H}$ NMR (DMSO- $\left.d_{6}\right), \delta$ (ppm) 0.91 (t, 3H, $J=$ $6.8 \mathrm{~Hz}), 1.26-1.40(\mathrm{~m}, 4 \mathrm{H}), 1.60-1.73(\mathrm{~m}, 2 \mathrm{H}), 1.92-2.19(\mathrm{~m}, 2 \mathrm{H}), 2.26(\mathrm{~s}, 3 \mathrm{H}), 2.62-2.76(\mathrm{~m}, 2 \mathrm{H})$, 3.12-3.30 (m, 2H), 3.64-3.75 (m, 2H), $4.62(\mathrm{dt}, 1 \mathrm{H}, J=7.8,8.4 \mathrm{~Hz}), 7.10-7.25(\mathrm{~m}, 3 \mathrm{H}$, Ar) 7.35 (dd, 1H, $J=7.2,1.8 \mathrm{~Hz}$ ), 9.64 (br. s, $1 \mathrm{H}), 10.25^{*}$ (s, 1H), 10.84 (s, 1H), 12.25* (br. s, 1H); * - 
signals of the minor trans-diastereomer. Anal. Calc. for $\mathrm{C}_{17} \mathrm{H}_{27} \mathrm{ClN}_{2} \mathrm{O}: \mathrm{C}, 65.68 ; \mathrm{H}, 8.75 ; \mathrm{N}, 9.01$. Found: C, 65.57; H, 8.66; N, 8.93.

\subsubsection{0. o-Toluidide of $N$-hexylproline (4l)}

Yield 56\%; mp $148-150{ }^{\circ} \mathrm{C}$ (ethyl acetate); ${ }^{1} \mathrm{H}$ NMR (DMSO- $\left.d_{6}\right), \delta$ (ppm) 0.89 (t, 3H, $J=$ $6.6 \mathrm{~Hz}), 1.25-1.40(\mathrm{~m}, 6 \mathrm{H}), 1.58-1.72(\mathrm{~m}, 2 \mathrm{H}), 1.92-2.20(\mathrm{~m}, 2 \mathrm{H}), 2.25(\mathrm{~s}, 3 \mathrm{H}), 2.60-2.75(\mathrm{~m}, 2 \mathrm{H})$, 3.10-3.32 (m, 2H), 3.64-3.74 (m, 2H), 4.49 (dt, 1H, $J=8.1,7.5 \mathrm{~Hz}), 4.67-4.73 *(\mathrm{~m}, 1 \mathrm{H}), 7.10-7.39$ (m, 4H, Ar), 9.57 (br. s, 1H), 10.11* (s, 1H), $10.51(\mathrm{~s}, 1 \mathrm{H}), 12.20^{*}$ (br. s, 1H); * - signals of the minor trans-diastereomer. Anal. Calc. for $\mathrm{C}_{18} \mathrm{H}_{29} \mathrm{ClN}_{2} \mathrm{O}: \mathrm{C}, 66.54 ; \mathrm{H}, 9.00 ; \mathrm{N}, 8.62$. Found: C, $66.41 ; \mathrm{H}, 8.90 ; \mathrm{N}, 8.54$.

\subsubsection{1. o-Toluidide of N-benzylproline (4m)}

Yield 75\%; mp 213-215 ${ }^{\circ} \mathrm{C}(1,4-$ dioxane/toluene, $1: 1) ;{ }^{1} \mathrm{H}$ NMR (DMSO- $\left.d_{6}\right), \delta$ (ppm) 1.88$2.10(\mathrm{~m}, 2 \mathrm{H}), 2.06(\mathrm{~s}, 3 \mathrm{H}), 2.60-2.73(\mathrm{~m}, 2 \mathrm{H}), 3.55-3.70(\mathrm{~m}, 2 \mathrm{H}), 4.47(\mathrm{dd}, 2 \mathrm{H}, J=6.9,13.5 \mathrm{~Hz})$, $4.55(\mathrm{dt}, 1 \mathrm{H}, J=6.9,8.1 \mathrm{~Hz}), 7.01-7.22$ (m, 4H, Ar), 7.41-7.60 (m, 5H, Ar), 9,85 (br. s, 1H), 10.36 (s, 1H). Anal. Calc. for $\mathrm{C}_{19} \mathrm{H}_{23} \mathrm{ClN}_{2} \mathrm{O}: \mathrm{C}, 68.97 ; \mathrm{H}, 7.01 ; \mathrm{N}, 8.47$. Found: C, 68.86; H, 6.91; N, 8.35.

\subsubsection{2. o-Toluidide of $N$-cyclohexylproline (4n)}

Yield 56\%; mp 244-246 ${ }^{\circ} \mathrm{C}(1,4-$ dioxane/toluene, $1: 1) ;{ }^{1} \mathrm{H}$ NMR (DMSO- $\left.d_{6}\right), \delta$ (ppm) 1.18$1.40(\mathrm{~m}, 6 \mathrm{H}), 1.84-1.93(\mathrm{~m}, 2 \mathrm{H}), 1.97-2.14(\mathrm{~m}, 4 \mathrm{H}), 2.24(\mathrm{~s}, 3 \mathrm{H}), 2.54-2.60(\mathrm{~m}, 2 \mathrm{H}), 3.25-3.40(\mathrm{~m}$, 2H), 3.55-3.69 (m, 1H), 4.75 (dt, 1H, $J=7.5,9.0 \mathrm{~Hz}), 7.13-7.39(\mathrm{~m}, 4 \mathrm{H}), 9.36$ (br. s, 1H), 10.30* (s, 1H), $10.68(\mathrm{~s}, 1 \mathrm{H}), 11.93 *$ (br. s, 1H); * signals of the minor trans-diastereomer. Anal. Calc. for $\mathrm{C}_{18} \mathrm{H}_{27} \mathrm{ClN}_{2} \mathrm{O}: \mathrm{C}, 66.96 ; \mathrm{H}, 8.43 ; \mathrm{N}, 8.68$. Found: C, 66.81; H, 8.32; N, 8.55.

\subsubsection{1,4-Xylidide of $N$-cyclohexylproline (4o)}

Yield 37\%; mp 248-250 ${ }^{\circ} \mathrm{C}(\mathrm{MeCN}) ;{ }^{1} \mathrm{H}$ NMR (DMSO- $\left.d_{6}\right), \delta(\mathrm{ppm})$ 1.18-1.40 (m, 6H), 1.85-1.92 (m, 2H), 1.98-2.14 (m, 4H), 2.17 (s, 3H), 2.23 (s, 3H), 2.46-2.54 (m, 2H), 3.14-3.36 (m, 2H), 3.42-3.63 (m, 1H), 4.56-4.78 (m, 1H), $6.92(\mathrm{~d}, 1 \mathrm{H}, J=8.4 \mathrm{~Hz}), 6.97(\mathrm{~s}, 1 \mathrm{H}), 7.13(\mathrm{~d}, 1 \mathrm{H}, J=$ $8.4 \mathrm{~Hz}$ ), 9.20 (br. s, 1H), 10.11* (s, 1H), 10.50 (s, 1H), 11.80* (br. s, 1H); * - signals of the minor trans-diastereomer. Anal. Calc. for $\mathrm{C}_{18} \mathrm{H}_{27} \mathrm{ClN}_{2} \mathrm{O}$ : C, 67.74; H, 8.68; N, 8.32. Found: C, 67.68; H, $8.52 ; \mathrm{N}, 8.27$. 
Yield 38\%; mp 222-224 ${ }^{\circ} \mathrm{C}(\mathrm{MeCN}) ;{ }^{1} \mathrm{H}$ NMR (DMSO- $\left.d_{6}\right), \delta(\mathrm{ppm})$ 1.18-1.42 (m, 6H), 1.86-1.95 (m, 2H), 2.00-2.16 (m, 4H), 2.24 (s, 3H), 2.54-2.60 (m, 2H), 3.25-3.40 (m, 2H), 3.55-3.69 (m, 1H), 4.75 (dt, 1H, J = 7.5, 9.0 Hz), 7.13-7.39 (m, 4H), 9.36 (br. s, 1H), 10.30* (s, 1H), 10.68 (s, $1 \mathrm{H}), 11.93^{*}$ (br. s, $1 \mathrm{H}$ ); * - signals of the minor trans-diastereomer. Anal. Calc. for $\mathrm{C}_{17} \mathrm{H}_{24} \mathrm{Cl}_{2} \mathrm{~N}_{2} \mathrm{O}$ : C, 59.48; H, 7.05; N, 8.16. Found: C, 59.36; H, 6.94; N, 8.07.

\subsection{Biological activity}

\subsubsection{Surface local anaesthetic activity assay}

Surface anaesthetic activity was evaluated in white New Zealand rabbits using modified Regnier corneal reflex test [23]. Briefly, aqueous solutions (1\%, $0.25 \mathrm{ml})$ of compounds 4a-p or reference drugs were instilled into the conjunctival sac of the animals during $30 \mathrm{sec}$. The tactile stimulations of the rabbit cornea (up to 100 in a series) with the pointer were applied in 8 min after the treatment and then in the define intervals $(10,12,15 \mathrm{~min}$ and then every $5 \mathrm{~min})$. The summation of numbers of the stimulations required to cause the corneal reflex during $1 \mathrm{~h}$ (13 series) provided the Regnier index. The duration of the anaesthesia was estimated as a time required for complete restoration of the corneal reflex. Each compound was tested in 6 animals.

\subsubsection{Infiltration local anaesthetic activity assay}

Infiltration anaesthetic activity of the compounds was evaluated in Wistar rats using modification of the reported method [24]. Briefly, after identification of sensitive areas on the shaved skin of lumbar region of the rat back and determination of the electrical stimulation (rectangular pulses, 0.36 to14.0 $\mathrm{V}, 0.3 \mathrm{~ms}, 50 \mathrm{~Hz}$ ) threshold initiating the surface muscle contraction, the animals were injected with $0.5 \%$ solution of the tested compounds or reference drugs in saline $(0.2 \mathrm{ml}$, intradermally and $0.2 \mathrm{ml}$, subcutaneously). The electrical stimulation required to cause the muscle contraction was measured in 3 and 5 min after the injection; then the measurements were continued with 5 min intervals until recovery to the initial threshold value. The depth of anaesthesia was expressed as a percentage change in the stimulation threshold compare to the initial value. Increase of the stimulation threshold value more than 2 times was considered as $100 \%$ anaesthesia. Each compound was evaluated on 6 rats.

\subsubsection{Antiarrhythmic activity assay}

Antiarrhythmic activity was evaluated in Swiss albino mice using calcium chloride-induced arrhythmia model [28]. The compounds and reference drugs were administrated i.v. in the doses up 
to $1 / 2 \mathrm{LD}_{50}$. After $15 \mathrm{~min}$, cardiac arrhythmia was induced by i.v. injection of calcium chloride solution $(3 \%, 280 \mathrm{mg} / \mathrm{kg})$. The antiarrhythmic efficacy of the compounds was expressed as mean effective doses $\left(\mathrm{ED}_{50}\right)$ preventing arrhythmia associated mortality.

\subsubsection{Toxicity evaluation}

The acute toxicity of the compounds was determined using albino Swiss mice of both sexes with body weight $18-22 \mathrm{~g}$. The aqueous solutions of the compounds were injected via the tail vein in increasing doses. After the treatment, animals were observed for possible mortality cases and behavioural changes for $72 \mathrm{~h}$. $\mathrm{LD}_{50}$ values were estimated according to reported method [29].

\section{Acknowledgments}

We acknowledge financial support of Russian Ministry of Education and Science.

\section{References}

[1] A. Borgeat, J. Aguirre, Curr. Opin. Anaesthesiol. 23 (2010) 466-471.

[2] J. Guindon, J.-S. Walczak, P. Beaulieu, Drugs 67 (2007) 2121-2133.

[3] L. B. Santamaria, D. Schifilliti, D. La Torre, V. Fodale, Surg. Oncol. 19 (2010) 63-81.

[4] A. S. Gaffen, D. A. Haas, J. Can. Dent. Assoc. 75 (2009) 649.

[5] R. Fuzier, M. Lapeyre-Mestre, K. Samii, J.-L. Montastruc, Drug Saf. 32 (2009) 345-356.

[6] R. Fuzier, M. Lapeyre-Mestre, Expert Opin. Drug Saf. 9 (2010) 759-769.

[7] M. H. Holmdahl, Acta Anaesthesiol. Scand. Suppl 113 (1998) 8-12.

[8] K. G. Dhuner, B. Egner, B. A. F. Ekenstam, O. Oljelund, L. R. Ulfendahl, Br. J. Anaesth. 28 (1956) 503-506.

[9] B. T. Af Ekenstam, B. Egner, G. Pettersson, Acta Chem. Scand. 11 (1957) 1183-1190.

[10] B. T. Af Ekenstam, C. Bovin, WO Patent 8500599 (1985); Chem. Abstr. 103 (1985) 160393.

[11] N. T. Pryanishnikova, A. S. Lebedeva, A. M. Likhosherstov, G. I. Gurevich, M. A. Izraélit, I. V. Fedina, M. F. Runova, M. I. Shmar'yan, A. P. Skoldinov, Pharm. Chem. J. 5 (1971) 7-9.

[12] L. E. Mather, Expert Opin. Drug Metab. Toxicol. 6 (2010) 1313-1332.

[13] G. A. Albright, Anesthesiology 51 (1979) 285-287.

[14] G. Di Gregorio, J. M. Neal, R. W. Rosenquist, G. L. Weinberg, Reg. Anesth. Pain. Med. 35 (2010) 181-187. 
[15] J. L. Southworth, V. A. McKusick, E. C. Pierce, 2 ${ }^{\text {nd }}$, F. L. Rawson, Jr. J. Am. Med. Assoc. 143 (1950) 717-721.

[16] F. E. Goda, A. A. M. Abdel-Aziz, H. A. Ghoneim, Bioorg. Med. Chem. 13 (2005) 3175-3183.

[17] C. Zalaru, F. Dumitrascu, C. Draghici, E. Cristea, I. Tarcomnicu, ARKIVOC (ii) (2008) 308314.

[18] A. Nardi, N. Damann, T. Hertrampf, A. Kless, ChemMedChem 7 (2012) 1712-1740.

[19] X. Guo, N. A. Castle, D. M. Chernoff, G. R. Strichartz, Ann. N. Y. Acad. Sci. 625 (1991) 181199.

[20] C. H. Kindler, M. Paul, H. Zou, C. Liu, B. D. Winegar, A. T. Gray, C. S. Yost, J. Pharmacol. Exp. Ther. 306 (2003) 84-92.

[21] A. K. Grenader, M. S. Okon, A. K. Filippov, V. I. Porotikov, Pharm. Chem. J. 20 (1986) 154157.

[22] A. M. Likhosherstov, N. T. Pryanishnikova, A. S. Lebedeva, A. P. Skoldinov, Pharm. Chem. J. 4 (1970), 492-495.

[23] J. Regnier, Bull. Sci. Pharm. 30 (1923) 580-586.

[24] E. Bulbring, I. Wajda, J. Pharmacol. 85 (1945) 78-84.

[25] A. De Luca, S. Talon, M. De Bellis, J.-F. Desaphy, G. Lentini, F. Corbo, A. Scilimati, C. Franchini, V. Tortorella, D. C. Camerino, Mol. Pharmacol. 64 (2003) 932-945.

[26] C. Ghelardini, J. F. Desaphy, M. Muraglia, F. Corbo, R. Matucci, A. Dipalma, C. Bertucci, M. Pistolozzi, M. Nesi, M. Norcini, C. Franchini, D. C. Camerino, Neuroscience 169 (2010) 863-873.

[27] A. Carrieri, M. Muraglia, F. Corbo, C. Pacifico, Eur. J. Med. Chem. 44 (2009) 1477-1485.

[28] V. V. Gorbunova, N. P. Gorbunov, Farmakol. Toksikol. 46(3) (1983) 48-50.

[29] V. B. Prozorovsky, M. P. Prozorovskaya, V. M. Demchenko, Farmakol. Toksikol. 41 (1978) 497-503. 


\section{Figure captures:}

Figure 1. Local anaesthetics - arylamides of amino acids

Figure 2. Infiltration anaesthesia activity of selected compounds: $4 \mathbf{c}(A), \mathbf{4 d}(B), 4 l(C)$ and 40 (D). Data are mean values \pm SEM

Scheme 1. Synthesis of $N$-alkyl derivatives of proline anilides (4a-4p) 
Table 1. Surface anaesthetic activities of the synthesized compounds $\mathbf{4 a - 4 p}$

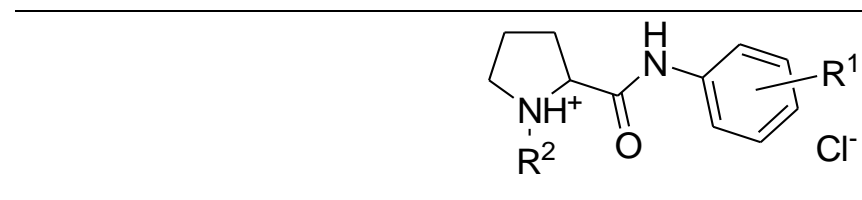

\begin{tabular}{|c|c|c|c|c|}
\hline \multirow{2}{*}{ Compound } & \multirow{2}{*}{$\mathbf{R}^{1}$} & \multirow{2}{*}{$\mathbf{R}^{2}$} & \multicolumn{2}{|c|}{$\begin{array}{c}\text { Surface anaesthesia (rabbit } \\
\text { corneal reflex) }\end{array}$} \\
\hline & & & $\begin{array}{c}\text { Regnier } \\
\text { Index }^{\mathrm{a}} \pm \text { SEM }\end{array}$ & $\begin{array}{l}\text { Duration, } \\
\min \pm \text { SEM }\end{array}$ \\
\hline $4 a$ & $2-\mathrm{CH}_{3}$ & $\mathrm{CH}_{3}$ & NA & NA \\
\hline $4 b$ & $2-\mathrm{CH}_{3}$ & $\mathrm{C}_{2} \mathrm{H}_{5}$ & NA & NA \\
\hline $4 c$ & $2-\mathrm{CH}_{3}$ & $n-\mathrm{C}_{4} \mathrm{H}_{9}$ & $1030.0 \pm 59.9$ & $49.4 \pm 4.5$ \\
\hline $4 d$ & $2,6-\left(\mathrm{CH}_{3}\right)_{2}$ & $n-\mathrm{C}_{4} \mathrm{H}_{9}$ & $1258.0 \pm 4.8$ & $57.5 \pm 2.1$ \\
\hline $4 e$ & $2,4-\left(\mathrm{CH}_{3}\right)_{2}$ & $n-\mathrm{C}_{4} \mathrm{H}_{9}$ & $1104.0 \pm 62.3$ & $59.0 \pm 7.8$ \\
\hline $4 f$ & $2-\mathrm{CF}_{3}$ & $n-\mathrm{C}_{4} \mathrm{H}_{9}$ & $467.0 \pm 93.8$ & $20.4 \pm 3.6$ \\
\hline $4 g$ & $2-\mathrm{C}_{2} \mathrm{H}_{5}$ & $n-\mathrm{C}_{4} \mathrm{H}_{9}$ & $73.5 \pm 15.9$ & $12.7 \pm 1.4$ \\
\hline $4 h$ & $2-\mathrm{I}$ & $n-\mathrm{C}_{4} \mathrm{H}_{9}$ & $429.0 \pm 97.3$ & $20.3 \pm 1.1$ \\
\hline $4 \mathbf{i}$ & $2,4-\mathrm{Cl}_{2}$ & $n-\mathrm{C}_{4} \mathrm{H}_{9}$ & NA & NA \\
\hline $4 \mathbf{j}$ & $2,4-\mathrm{Br}_{2}$ & $n-\mathrm{C}_{4} \mathrm{H}_{9}$ & NA & NA \\
\hline $4 k$ & $2-\mathrm{CH}_{3}$ & $n-\mathrm{C}_{5} \mathrm{H}_{11}$ & $1165.6 \pm 58.3$ & $59.8 \pm 2.8$ \\
\hline 41 & $2-\mathrm{CH}_{3}$ & $n-\mathrm{C}_{6} \mathrm{H}_{13}$ & $1225.0 \pm 75.0$ & $75.7 \pm 3.1$ \\
\hline $4 m$ & $2-\mathrm{CH}_{3}$ & $\mathrm{PhCH}_{2}$ & NA & NA \\
\hline $4 n$ & $2-\mathrm{CH}_{3}$ & & $1002.3 \pm 77.0$ & $46.5 \pm 2.7$ \\
\hline 40 & $2,4-\left(\mathrm{CH}_{3}\right)_{2}$ & & $1226.0 \pm 30.0$ & $73.2 \pm 3.7$ \\
\hline $4 p$ & $2-\mathrm{Cl}$ & & $734.8 \pm 76.5$ & $41.3 \pm 2.4$ \\
\hline
\end{tabular}

Cyclomecaine $2,4,6-\left(\mathrm{CH}_{3}\right)_{3} \quad \square \quad 1300.0 \pm 0.0 \quad 124.5 \pm 11.2$

$\begin{array}{lll}\text { Lidocaine } & 831.7 \pm 55.6 & 37.8 \pm 3.7\end{array}$

Ropivacaine $\quad 1001.1 \pm 86.1 \quad 58.4 \pm 2.7$

$\begin{array}{lll}\text { Bupivacaine } & 1218.0 \pm 29.3 & 94.0 \pm 3.5\end{array}$

${ }^{\text {a }}$ Regnier Index - indicator of the anaesthesia depth during first $60 \mathrm{~min}$ after the compound application expressed as a sum of the threshold tactile stimuli needed to induce corneal reflex (13 series, up to 100 stimuli per one series) [23] 
Table 2. Antiarrhythmic activity and acute toxicity $\left(\mathrm{LD}_{50}\right)$ of $N$-alkyl derivatives of proline anilides $(\mathbf{4 a}-\mathbf{4} \mathbf{p})$

\begin{tabular}{|c|c|c|c|c|c|}
\hline Compound & $\mathbf{R}^{1}$ & $\mathbf{R}^{2}$ & $\begin{array}{c}\mathrm{LD}_{50}, \mathrm{mg} / \mathrm{kg} \\
\left(\text { mice, } i . v_{.}\right)\end{array}$ & $\begin{array}{c}\mathrm{ED}_{50}, \mathrm{mg} / \mathrm{kg} \\
\left(\text { mice, } i . v_{.}\right)\end{array}$ & $\begin{array}{c}\text { Antiarrhythmic } \\
\text { index } \\
\left(\mathrm{LD}_{\mathbf{5 0}} / \mathrm{ED}_{\mathbf{5 0}}\right)\end{array}$ \\
\hline $4 \mathbf{a}$ & $2-\mathrm{CH}_{3}$ & $\mathrm{CH}_{3}$ & $32.5(26.0-40.0)$ & $>16.3^{\mathrm{a}}$ & NA \\
\hline $4 b$ & $2-\mathrm{CH}_{3}$ & $\mathrm{C}_{2} \mathrm{H}_{5}$ & $36.8(26.0-50.0)$ & $>18.4^{\mathrm{a}}$ & NA \\
\hline $4 c$ & $2-\mathrm{CH}_{3}$ & $n-\mathrm{C}_{4} \mathrm{H}_{9}$ & $16.3(14.0-19.0)$ & $5.4(4.0-7.5)$ & 3.0 \\
\hline $4 d$ & $2,6-\left(\mathrm{CH}_{3}\right)_{2}$ & $n-\mathrm{C}_{4} \mathrm{H}_{9}$ & $9.2(6.7-12.7)$ & $>4.6^{\mathrm{a}}$ & NA \\
\hline $4 e$ & $2,4-\left(\mathrm{CH}_{3}\right)_{2}$ & $n-\mathrm{C}_{4} \mathrm{H}_{9}$ & $60.0(48.0-74.0)$ & $>30.0^{\mathrm{a}}$ & NA \\
\hline $4 f$ & $2-\mathrm{CF}_{3}$ & $n-\mathrm{C}_{4} \mathrm{H}_{9}$ & $35.5(29.0-42.0)$ & $5.8(4.2-8.0)$ & 6.1 \\
\hline $4 \mathrm{~g}$ & $2-\mathrm{C}_{2} \mathrm{H}_{5}$ & $n-\mathrm{C}_{4} \mathrm{H}_{9}$ & $30.0(24.0-38.0)$ & $7.1(5.9-8.4)$ & 4.2 \\
\hline $4 h$ & 2-I & $n-\mathrm{C}_{4} \mathrm{H}_{9}$ & $41.0(35.0-47.0)$ & $7.3(5.3-10.0)$ & 5.6 \\
\hline $4 i$ & $2,4-\mathrm{Cl}_{2}$ & $n-\mathrm{C}_{4} \mathrm{H}_{9}$ & $32.5(26.0-40.0)$ & $>16.3^{\mathrm{a}}$ & NA \\
\hline $\mathbf{4 j}$ & $2,4-\mathrm{Br}_{2}$ & $n-\mathrm{C}_{4} \mathrm{H}_{9}$ & $239.0(190.0-300.0)$ & $69.0(50.0-95.0)$ & 3.5 \\
\hline $4 \mathbf{k}$ & $2-\mathrm{CH}_{3}$ & $n-\mathrm{C}_{5} \mathrm{H}_{11}$ & $32.5(28.0-38.0)$ & $5.5(4.0-7.5)$ & 5.9 \\
\hline 41 & $2-\mathrm{CH}_{3}$ & $n-\mathrm{C}_{6} \mathrm{H}_{13}$ & $35.5(29.0-42.0)$ & $5.6(4.9-6.4)$ & 6.3 \\
\hline $4 m$ & $2-\mathrm{CH}_{3}$ & $\mathrm{PhCH}_{2}$ & $35.5(31.0-40.0)$ & $10.9(8.0-15.0)$ & 3.3 \\
\hline $4 n$ & $2-\mathrm{CH}_{3}$ & & $12.9(10.0-16.0)$ & $>6.5^{\mathrm{a}}$ & NA \\
\hline 40 & $2,4-\left(\mathrm{CH}_{3}\right)_{2}$ & & $65.0(56.0-75.0)$ & $8.9(7.8-10.2)$ & 7.3 \\
\hline $4 p$ & $2-\mathrm{Cl}$ & & $95.0(76.0-119.0)$ & $13.7(10-19)$ & 6.9 \\
\hline Cyclomecaine & $2,4,6-\left(\mathrm{CH}_{3}\right)_{3}$ & & $15.0(12.0-17.0)$ & $2.9(2.2-3.0)$ & 5.2 \\
\hline Lidocaine & & & $39.3(34.2-44.5)$ & $7.7(5.9-9.4)$ & 5.1 \\
\hline Ropivacaine & & & $14.1(12.0-17.0)$ & $3.7(2.6-5.0)$ & 3.8 \\
\hline Bupivacaine & & & $8.9(7.5-10.6)$ & $3.5(3.1-4.0)$ & 2.5 \\
\hline
\end{tabular}

${ }^{\mathrm{a}}$ Appeared to be inactive in the dose of $1 / 2 \mathrm{LD}_{50}$ 
<smiles>CCN(CC)CC(=O)Nc1c(C)cccc1C</smiles><smiles>CCN(CC)CC(=O)Nc1c(C)cc(C)cc1C</smiles><smiles>CCCNC(C)C(=O)Nc1ccccc1C</smiles>

Lidocaine

Trimecaine

Prilocaine<smiles>CCCCNCC(=O)Nc1c(C)cccc1Cl</smiles><smiles>CCCCN1CCCCC1C(=O)Nc1c(C)cccc1C</smiles><smiles>CCCN1CCCC[C@H]1C(=O)Nc1c(C)cccc1C</smiles>

Butanilicaine

Bupivacaine

Ropivacaine
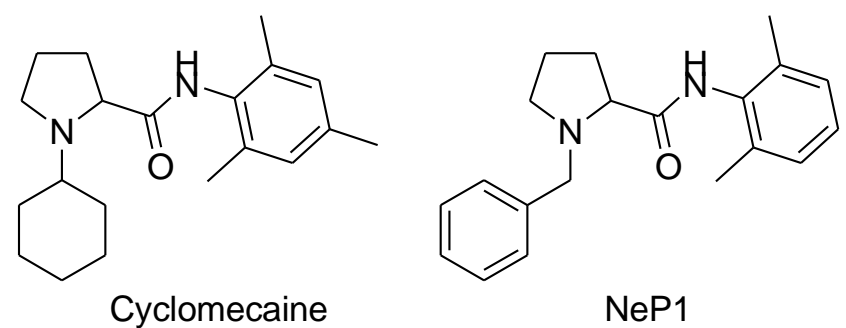

Cyclomecaine

$\mathrm{NeP1}$

Figure 1 

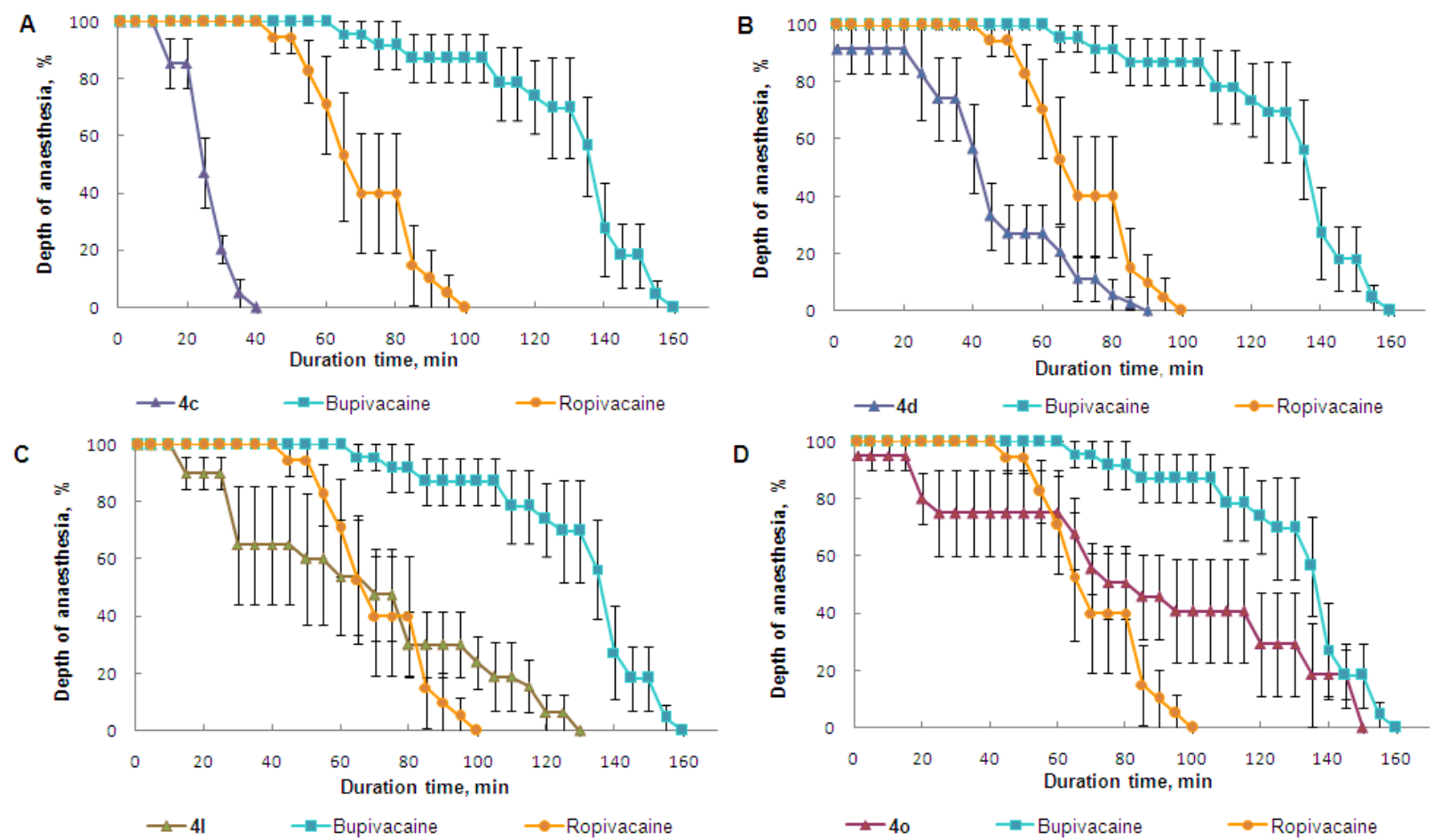

Figure 2 


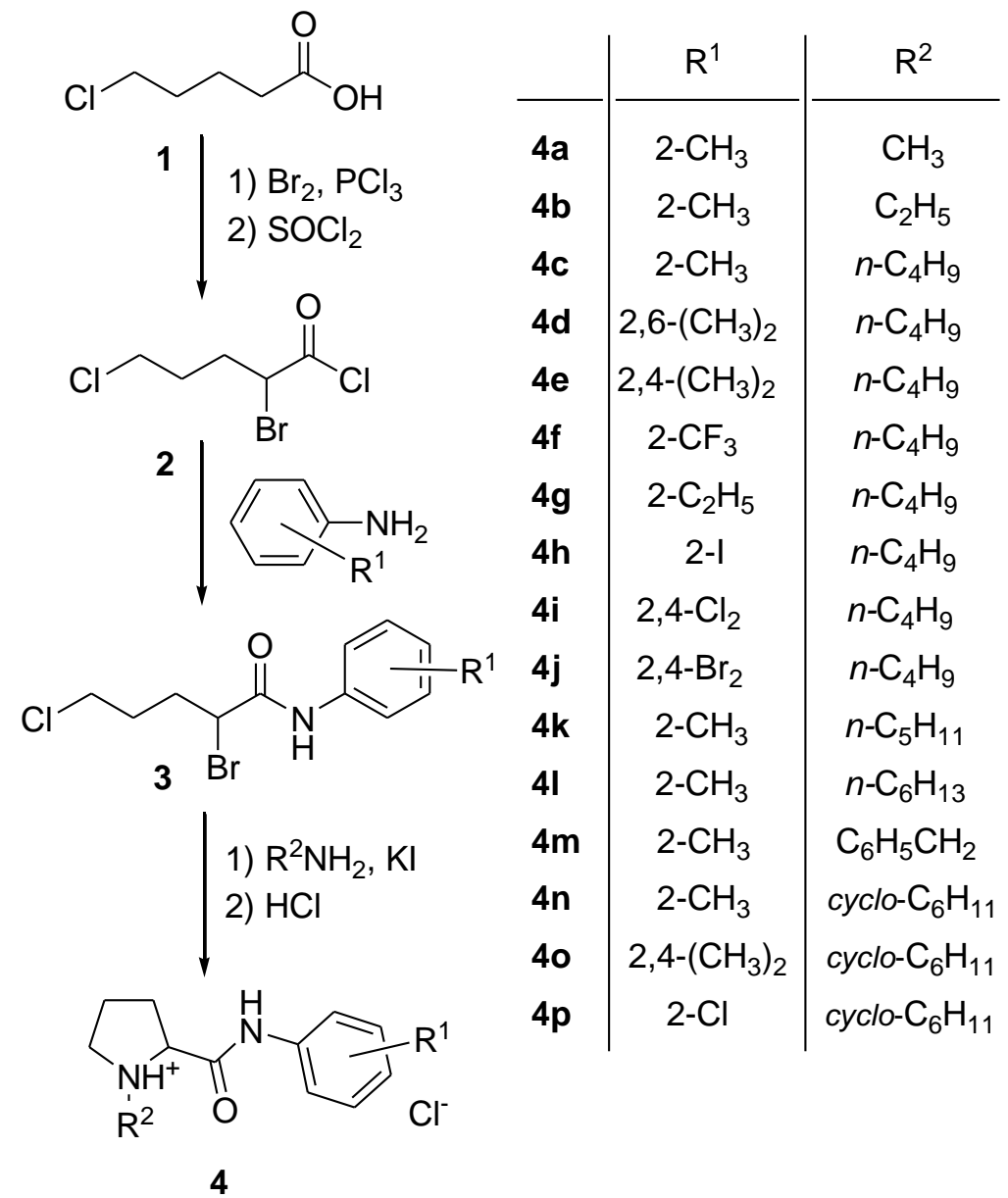

Scheme 1 